\title{
DESKRIPSI MINAT DAN HASIL BELAJAR SISWA DENGAN MODEL DIRECT INSTRUCTION BERBASIS MIND MAPPING PADA PEMBELAJARAN IPA DI SMPN 3 KEPAHIANG
}

\author{
Aulia Wulandari*, Connie, Eko Risdianto \\ Program Studi S1 Pendidikan Fisika Fakultas Keguruan dan Ilmu Pendidikan Universitas Bengkulu \\ Jl. WR Supratman Kandang Limun Bengkulu \\ E-mail*: auliawulandaribakri@gmail.com
}

\begin{tabular}{c|c|c|c} 
Diterima 26 Juli 2019 & Direvisi 6 April 2020 & Disetujui 24 April 2020 & Dipublikasikan 30 April 2020 \\
\hline \multicolumn{4}{c}{ https://doi.org/10.33369/jkf.3.1.51-58 } \\
\hline
\end{tabular}

\begin{abstract}
ABSTRAK
Penelitian ini bertujuan untuk mendeskripsikan minat belajar, kemampuan siswa membuat Mind Mapping, dan hasil belajar siswa dengan model Direct Instruction berbasis Mind Mapping pada pembelajaran IPA di SMP Negeri 3 Kepahiang. Metode penelitian yang digunakan adalah deskriptif kualitatif. Subjek penelitian adalah siswa kelas VII D SMP Negeri 3 Kepahiang tahun pelajaran 2018/2019 yang berjumlah 25 siswa. Teknik pengumpulan data menggunakan angket untuk melihat minat belajar siswa, lembar test untuk melihat hasil belajar siswa dan lembar tugas untuk melihat kemampuan siswa membuat Mind Mapping. Berdasarkan hasil tes evaluasi pada penelitian pertemuan 1 diperoleh hasil belajar siswa dalam kategori sangat kurang. Pertemuan 2 diperoleh hasil belajar siswa dalam kategori sangat kurang. Pada pertemuan 3 diperoleh hasil belajar siswa dalam kategori sangat baik. Berdasarkan hasil angket minat pada pertemuan 1 rata-rata persentase minat belajar dalam kategori kurang. Pada pertemuan 2 persentase rata-rata minat belajar Siswa dalam kategori kurang. Pada pertemuan 3 persentase rata-rata minat belajar siswa dalam kategori baik. Berdasarkan hasil lembar tugas membuat mind mapping pada pertemuan 1 diperoleh skor rata-rata kelas dalam kategori sangat kurang. Pertemuan 2 diperoleh skor rata-rata dalam kategori baik. Pada pertemuan 3 diperoleh skor ratarata kelas siswa dalam kategori baik.
\end{abstract}

Kata Kunci: Model Pembelajaran Direct Instruction, Minat Belajar, Hasil Belajar, Mind Mapping.

\begin{abstract}
This study aims to describe student's interest, ability in making mind mapping, and learning outcomes of students with a mind mapping based direct learning model in science learning in SMPN 3Kepahiang. The research method used was descriptive qualitative. The research subjects were students of class VII D SMP Negeri 3 Kepahiang 2018/2019 school year who received 25 students. The technique of collecting data using a questionnaire to see student learning interests, test sheets to see student learning outcomes and task sheets to see the ability of students to make mind mapping. Based on the results of testing in the first meeting research obtained student learning outcomes in the very less category. The second meeting obtained student learning outcomes in very fewer categories. In the third meeting, the students' learning outcomes were obtained in a very good category. Based on the results of the questionnaire interest in the first meeting the average percentage of interest in learning in the category was less. At the second meeting, the percentage of students' average interest in learning is in the less category. At the third meeting, the percentage of students' average interest in learning is in a good category. Based on the results of the assignment sheet making mind mapping at the first meeting, the average score in the category is very bad. The second meeting obtained an average score in the good category. At the third meeting, the average score of the students in the good category was obtained.
\end{abstract}

Keywords: Direct Instruction Learning Model, Learning Interest,Learning Outcomes, Mind Mapping.

\section{Pendahuluan}

Mata pelajaran Ilmu Pengetahuan Alam (IPA) merupakan salah satu mata pelajaran wajib yang diujikan dalam Ujian Nasional SMP. Namun, pelajaran IPA terutama fisika masih dianggap sebagai pelajaran yang sulit oleh sebagian besar siswa SMP. Banyak siswa yang tidak tertarik dengan pelajaran fisika, siswa berangggapan bahwa fisika itu sulit karena kebanyakan teori dan 
rumus-rumus yang harus dipelajari. Hal ini disebabkan oleh beberapa faktor. Kemungkinan penyebab hal tersebut, antara lain faktor guru, faktor fasilitas, faktor lingkungan atau dari diri siswa itu sendiri. karena kurangnya pemahaman dari materi yang diberikan oleh guru. Siswa cenderung menghafalkan konsep fisika, sehingga siswa kesulitan untuk menjawab soal pemahaman. Sehingga membuat minat belajar siswa menjadi rendah.

Permasalahan yang sering dihadapi siswa adalah malas membuat catatan. Hal ini dikarenakan metode mencatat yang diterapkan kurang efektif yaitu hanya menerapkan metode mencatat tradisional saja. Menurut Sugiarto, catatan tradisional (biasa) memiliki karakteristik yaitu hanya berupa tulisan-tulisan saja, hanya dalam satu warna, untuk mereview ulang memerlukan waktu yang lama dan statis [1]. Metode mencatat tradisional dapat berdampak pada sedikitnya catatan yang dimiliki siswa sehingga siswa tidak memliki dokumentasi yang lengkap mengenai materi yang disampaikan oleh guru. Siswa juga kesulitan dalam mempelajari kembali materi yang sudah diberikan oleh guru. Cara seperti ini (mencatat tradisional) memiliki berbagai kelemahan seperti berikut (1) monoton, kaku dan membosankan (2) sulit untuk melihat secara utuh (3) hanya terpusat pada otak kiri saja (4) sukar untuk mencari kata kunci dan melihat hubungan antar sub-sub bagian[2]. Jadi, dengan metode mencatat seperti ini mempersulit siswa memahami konsep-konsep utama dengan melihat keterkaitan konsep-konsep saling berhubungan. Salah satu teknik mencatat yang dapat membantu siswa memahami keterkaitan antar konsep adalah Mind Mapping atau peta pikiran.

Peta pikiran adalah teknik pemanfaatan keseluruhan-otak dengan mengggunakan citra visual dan prasarana grafis lainnya untuk membentuk kesan [3]. Mind map adalah cara mencatat yang kreatif , efektif, dan secara harfiah akan "memetakan" pikiran-pikiran kita. Kita bisa membandingkan Mind Mapping dengan peta kota. Pusat mind map mirip dengan pusat kota. Pusat mind map mewakili ide terpenting. Jalan-jalan utama yang menyebar dari pusat mewakili pikiranpikiran utama dalam proses pemikiran kita, jalan-jalan sekunder mewakili pikiran-pikiran sekunder, dan seterusnya. Gambar-gambar atau bentuk-bentuk khusus dapat mewakili area-area yang menarik atau ide-ide menarik tertentu[4].

Pada saat membuat peta pikiran, siswa tidak hanya dapat menggunakan kata-kata saja, namun siswa juga dapat menggunakan garis, warna, simbol ataupun gambar yang mereka pahami untuk menggambarkan suatu konsep. Oleh karena itu, siswa akan selalu tertantang untuk dapat membuat peta pikiran yang menarik, mudah diingat, dan terintegrasi antara satu konsep dengan konsep lainnya yang akan memacu siswa untuk lebih aktif dalam pembelajaran. Dengan demikian, pembelajaran dengan media Mind Mapping sangat memberikan kebebasan pada siswa untuk mengeksplorasi dan mengonstruksi sendiri pemahamannya melalui kebebasan berimajinasi yang akan meningkatkan hasil belajar dan minat siswa. Minat adalah sikap jiwa orang seorang termasuk ketiga fungsi jiwanya (kognisi, konasi, dan emosi), yang tertuju pada sesuatu dan dalam hubungan itu unsur perasaan yang kuat [5]. Minat adalah kecenderungan yang tetap untuk memperhatikan dan mengenang beberapa kegiatan [6]. Minat belajar adalah rasa ketertarikan, perhatian, keinginan lebih yang dimiliki seseorang terhadap belajar. Dengan menumbuhkan minat belajar, siswa dapat meningkatkan hasil belajarnya. Oleh karena itu, kegiatan membuat Mind Mapping diharapkan dapat meningkatkan minat belajar siswa sehingga meningkatkan hasil belajarnya.

Kegiatan membuat mind mapping ini sangat cocok dengan model pembelajaran langsung atau Direct Instruction atau juga dikenal dengan istilah strategi belajar ekspositori dan whole class teaching. Pembelajaran langsung merupakan suatu model pembelajaran yang terdiri dari penjelasan guru mengenai konsep atau keterampilan baru terhadap siswa. Menurut Arends oleh Trianto adalah suatu model pembelajaran dirancang khusus untuk menunjang proses belajar siswa yang berkaitan dengan pengetahuan deklaratif dan pengetahuan prosedural yang terstruktur dengan baik, dapat diajarkan dengan pola kegiatan yang bertahap selangkah demi selangkah [1]. Model pengajaran langsung memberikan kesempatan siswa belajar dengan mengamati secara selektif, mengingat dan menirukan apa yang dimodelkan gurunya. Di samping itu, model pengajaran langsung mengutamakan pendekatan deklaratif dengan titik berat pada proses belajar konsep dan keterampilan motorik, sehingga menciptakan suasana pembelajaran bertanggung jawab dalam 
mengidentifikasi tujuan pembelajaran, struktur materi, dan keterampilan dasar yang akan diajarkan. Kemudian menyampaikan pengetahuan kepada siswa, memberikan permodelan/demonstrasi, memberikan kesempatan pada siswa untuk berlatih menerapkan konsep/keterampilan yang telah dipelajari, dan memberikan umpan balik.

Berdasarkan uraian di atas, dilakukan penelitian dengan judul "Deskripsi Hasil Dan Minat Belajar Siswa Dengan Model Direct Instruction Berbasis Mind Mapping Pada Pembelajaran IPA Di SMP Negeri 3 Kepahiang. Penelitian ini bertujuan (1) untuk mendeskripsikan hasil belajar siswa dengan menngunakan model Direct Instruction berbasis Mind Mapping pada pembelajaran IPA di SMP Negeri 3 Kepahiang, (2) untuk mendeskripsikan minat belajar siswa dengan menngunakan model Direct Instruction berbasis Mind Mapping pada pembelajaran IPA di SMP Negeri 3 Kepahiang, dan (3) untuk mendeskripsikan kemampuan membuat Mind Mapping siswa pada pembelajaran IPA di SMP Negeri 3 Kepahiang.

\section{Metodologi Penelitian}

Penelitian ini menggunakan metode deskriptif kualitatif. Dalam penelitian ini yang menjadi subjek penelitian adalah siswa kelas VII yang terdiri dari 25 siswa. Penelitian ini menggunakan teknik pengumpulan data dengan lembar tes, tugas, dan pengisian lembar angket. Lembar tes berisi 5 soal yang diberikan pada setiap siklus sebagai alat evaluasi, untuk melihat hasil belajar siswa setelah diterapkan model pembelajaran Direct Instruction berbasis Mind Mapping. Pengisian lembar angket diberikan kepada siswa untuk mengetahui minat belajar siswa terhadap mata pelajaran Fisika. Lembar angket yang digunakan mencakup empat indikator, yaitu perasaan senang, ketertarikan, keterlibatan dan perhatian siswa selama proses pembelajaran. Lembar angket berisi 30 pertanyaan yang akan di isi oleh siswa, lembar angket di isi oleh siswa sesudah pertemuan 1, sesudah pertemuan 2 dan sesudah pertemuan 3 menggunakan angket yang sama. Tugas yang diberikan peneliti untuk melihat kemampuan siswa membuat Mind Mapping dinilai berdasarkan kriteria penilaian Mind Mapping. Hasil penilaian dikategorikan dalam kategori sangat kurang, cukup, baik, atau sangat baik.

Untuk mengetahui keefektifan suatu metode dalam kegiatan pembelajaran, perlu dilakukan analisis data. Untuk penilaian tes, peneliti menjumlahkan nilai yang diperoleh siswa, selanjutnya dibagi dengan jumlah siswa yang mengikuti tes sehingga diperoleh nilai rata-rata. Nilai rata-rata ini didapat dengan menggunakan rumus :

$$
\bar{x}=\frac{\Sigma x}{\Sigma N}
$$

dengan $\bar{x}$ adalah nilai rata-rata, $\Sigma x$ adalah jumlah semua nilai siswa, dan $\Sigma N$ adalah jumlah siswa. Analisis data angket dilakukan dengan langkah skoring item pernyataan, skoring keseluruhan pernyataan, dan klasifikasi tingkat minat.

Pernyataan siswa untuk kriteria pernyataan positif diberi skor 4 (empat) untuk jawaban SS, skor 3 (tiga) untuk jawaban S. Skor 2 (dua) untuk jawaban TS dan skor 1 (satu) untuk jawaban STS, dan untuk kriteria pernyataan negatif diberi skor 4 (empat) untuk jawaban S dan skor 1 untuk jawaban SS. Untuk mengetahui skor setiap siswa maka digunakan:

$$
P=\frac{\Sigma m}{B \times N} \times 100
$$

dengan $\mathrm{P}$ adalah persentase, $\mathrm{m}$ adalah skor minat, $\mathrm{N}$ adalah jumlah siswa, dan $\mathrm{B}$ adalah skor maksimal. Untuk mengetahui tingkat minat siswa kelas VII D SMP Negeri 3 Kepahiang maka hasil penskoran diklasifikasikan. Karena jumlah total pernyataan untuk angket minat siswa adalah 30 maka skor minimal adalah $30(1 \times 30)$ dan skor maksimal adalah 120 (4x30) sehingga besar range adalah 90 (120-30). Lalu skor diklasifikasikan dalam 5 interval, maka lebar intervalnya adalah 18 (90:5) sehingga skor yang diperoleh dari minat siswa diklasifikasikan berdasarkan kategori yang dapat dilihat pada tabel 1 . 
Tabel 1. Kategori minat siswa

\begin{tabular}{ccc}
\hline Skor Minat Siswa & Persentase Minat $(\%)$ & Kategori Minat \\
\hline $103-120$ & $\geq 85$ & Sangat baik \\
$81-102$ & $70-84$ & Baik \\
$67-84$ & $55-69$ & Cukup \\
$49-66$ & $40-54$ & Kurang \\
$30-48$ & $\leq 39$ & Sangat kurang \\
\hline
\end{tabular}

Berdasarkan tabel 1, dalam penelitian ini minat dikategorikan tidak hanya dengan melihat skor total, namun dapat juga dengan melihat persentase minat siswa.

Untuk penilaian kemampuan Mind Mapping siswa, peneliti menggunakan kriteria penilaian Mind Mapping yang dapat dilihat pada tabel 2.

Tabel 2. Kriteria Penilaian Mind Map

\begin{tabular}{|c|c|c|c|c|}
\hline Kriteria & $\begin{array}{c}\text { Level } 4 \\
\text { (Sangat Baik) }\end{array}$ & $\begin{array}{l}\text { Level } 3 \\
\text { (Baik) }\end{array}$ & $\begin{array}{c}\text { Level } 2 \\
\text { ( Cukup) }\end{array}$ & $\begin{array}{c}\text { Level } 1 \\
\text { (Sangat Kurang) }\end{array}$ \\
\hline Kata kunci & $\begin{array}{l}\text { Penggunaan kata kunci } \\
\text { yang sangat efektif } \\
\text { (semua ide ditulis dalam } \\
\text { bentuk kata kunci) }\end{array}$ & $\begin{array}{l}\text { Semua ide ditulis } \\
\text { dalam kata kunci } \\
\text { dan kalimat }\end{array}$ & $\begin{array}{l}\text { Penggunaan } \\
\text { kata kunci } \\
\text { terbatas } \\
\text { (semua ide } \\
\text { ditulis dalam } \\
\text { bentuk } \\
\text { kalimat) }\end{array}$ & $\begin{array}{l}\text { Tidak ada atau } \\
\text { sangat terbatas } \\
\text { dalam pemilihan } \\
\text { kata kunci } \\
\text { (beberapa ide } \\
\text { ditulis dalam } \\
\text { bentuk paragraf) }\end{array}$ \\
\hline $\begin{array}{l}\text { Hubungan cabang } \\
\text { utama dengan } \\
\text { cabang lainnya }\end{array}$ & $\begin{array}{l}\text { Menggunakan lebih dari } \\
3 \text { cabang }\end{array}$ & $\begin{array}{l}\text { Menggunakan } 3 \\
\text { cabang }\end{array}$ & $\begin{array}{l}\text { Menggunakan } \\
2 \text { cabang }\end{array}$ & $\begin{array}{l}\text { Hanya } \\
\text { menggunakan } 1 \\
\text { cabang }\end{array}$ \\
\hline $\begin{array}{l}\text { Desain (warna } \\
\text { dan gambar) }\end{array}$ & $\begin{array}{l}\text { Mengggunakan warna } \\
\text { berbeda di setiap cabang } \\
\text { dan pemberian gambar/ } \\
\text { simbol pada ide sentral, } \\
\text { cabang utama dan } \\
\text { cabang } \\
\text { lainnya }\end{array}$ & $\begin{array}{l}\text { Mengggunakan } \\
\text { warna berbeda di } \\
\text { setiap cabang } \\
\text { dan pemberian } \\
\text { gambar/ simbol } \\
\text { hanya pada ide } \\
\text { sentral, dan cabang } \\
\text { utama }\end{array}$ & $\begin{array}{l}\text { Mengggunakan } \\
\text { warna berbeda } \\
\text { di setiap } \\
\text { cabang } \\
\text { dan pemberian } \\
\text { gambar/ } \\
\text { simbol pada } \\
\text { ide sentral }\end{array}$ & $\begin{array}{l}\text { Tidak } \\
\text { mengggunakan } \\
\text { warna dan gambar } \\
\text { atau } \\
\text { hanya } \\
\text { menggunakan satu } \\
\text { warna }\end{array}$ \\
\hline
\end{tabular}

Sumber: Adaptasi Mind Mapping Rubric From Ohassta (Ontario history and social sciences teachers' association)

Penilaian kemampuan siswa membuat Mind Mapping menggunakan rumus:

$$
N=\frac{R}{S M}
$$

dengan $\mathrm{N}$ adalah nilai yang dicari/diharapkan, $\mathrm{R}$ adalah skor mentah yang diperoleh, dan $\mathrm{SM}$ adalah skor maksimum ideal. Maka skor yang diperoleh dari kemampuan membuat Mind Mapping diklasifikasikan berdasarkan kategori pada tabel 3.

Tabel 3. Kategori kemampuan Mind Mapping siswa

\begin{tabular}{cc}
\hline Interval Nilai & Kategori \\
\hline $3,6-4$ & Sangat baik \\
$2,6-3,5$ & Baik \\
$1,6-2,5$ & Cukup \\
$0-1,5$ & Sangat kurang \\
\hline
\end{tabular}

Berdasarkan tabel 3, kategori kemampuan siswa membuat Mind Mapping dibagi menjadi 4 kategori yaitu sangat kurang, cukup, baik, dan sangat baik.

\section{Hasil Penelitian dan Pembahasan}

Penelitian ini bertujuan mendeskripsikan minat belajar, kemampuan membuat Mind Mapping dan hasil belajar setelah siswa mengikuti proses pembelajaran melalui model pembelajaran Direct Instruction (DI) dengan media Mind Mapping. Pengamatan dilakukan selama 3 pertemuan. Masingmasing pertemuan mengikuti prosedur berikut. Pada awal pembelajaran, siswa diberi angket yang 
berupa 30 soal untuk melihat minat siswa sebelum diberi perlakuan model pembelajaran Direct Instruction(DI) dengan media Mind Mapping. Pada fase menyampaikan tujuan dan mempersiapkan siswa, guru menyiapkan siswa untuk memulai proses pembelajaran dengan mengucapkan salam dan mengisi daftar hadir siswa. Guru memberikan apersepsi kepada siswa. Kemudian guru menyampaikan tujuan pembelajaran kepada siswa.

Pada Fase mendemonstrasikan pengetahuan/keterampilan, guru menyampaikan informasi tentang kegiatan yang akan dilakukan dengan menggunakan media Mind Mapping. Pada fase membimbing pelatihan, guru membimbing pelatihan siswa dan membagi siswa menjadi 4 kelompok. Guru memberikan penjelasan tentang langkah dan teknik melakukan percobaan. Siswa melakukan diskusi kelompok mengenai hasil penyelidikan dan menjawab pertanyaan dalam LKS. Pada fase mengecek pemahaman dan memberikan umpan balik, guru mengecek pemahaman dan memberikan umpan balik kepada siswa, melakukan diskusi kelas untuk menanamkan konsep, menyamakan persepsi tentang materi pelajaran fisika yakni Kalor.

Pada fase terakhir, memberikan kesempatan untuk pelatihan lanjutan dan penerapan, guru memberikan kesempatan untuk pelatihan lanjutan dan penerapan. Siswa mengumpulkan laporan observasi dan hasil diskusi kelompok. Siswa mengerjakan kuis secara individu. Guru mengumumkan kelompok yang terbaik di depan kelas. Guru meminta siswa untuk mempelajari materi pertemuan berikutnya. Sebelum mengakhiri pelajaran, guru memberikan materi secara singkat tentang Mind Mapping dan tata cata membuatnya yang dijelaskan secara lisan dan dituliskan di papan tulis. Setelah memastikan siswa mengerti, guru memberikan tugas kepada siswa untuk membuat Mind Mapping berdasarkan materi yang telah dipelajari. Kemudian guru mengucapkan salam.

Setelah proses penelitian, didapat hasil-hasil berikut.

\subsection{Minat Belajar}

Untuk melihat minat belajar siswa diberikan lembar angket yang berisi 30 pertanyaan yang harus dijawab. Di setiap pernyataan siswa harus memilih salah satu opsi yang telah tersedia pada setiap pernyataan, setiap opsi jawaban memiliki skor yang berbeda. Siswa mengisi angket berdasarkan dengan apa yang mereka lakukan. Minat keseluruhan pada pertemuan 1 dan 2 masuk dalam kategori kurang. Namun nilai keseluruhan pada pertemuan 2 mengalami peningkatan. Pada pertemuan 3 nilai keseluruhan minat masuk dalam kategori baik. Peningkatan minat dapat dilihat pada gambar 1 .

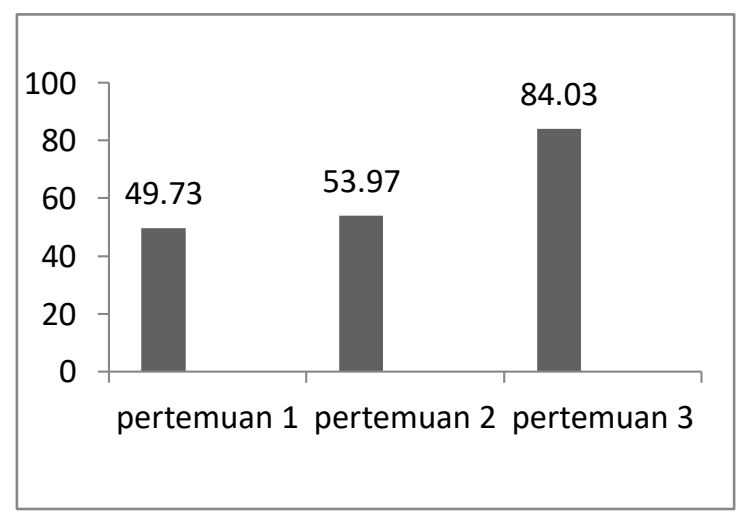

Gambar 1. Grafik Persentase Rata-Rata Minat Siswa

Terlihat pada gambar 1, hasil pengisian lembar angket minat belajar siswa, yaitu persentase rata-rata minat belajar pada pertemuan 1 adalah $49,73 \%$ dan dalam kategori kurang. Hal ini dikarenakan siswa kurang fokus untuk belajar dikarenakan waktu pembelajaran dilakukan saat classmeeting sehingga perasaan senang belajar menjadi rendah. Rendahnya perasaan senang bisa menjadi salah satu faktor internal yang menyebabkan rendahnya hasil belajar siswa. Pada pertemuan 2 persentase rata-rata minat siswa meningkat menjadi 53,97 \% namun masih dalam kategori kurang. Hal ini dikarenakan sebelum memulai pelajaran, sekolah memberikan instruksi untuk bersama-sama membersihkan kelas masing-masing sehinggga pada saat kegiatan belajar mengajar siswa dalam kondisi lelah sehingga siswa memiliki keterlibatan yang kurang. Pada 
pertemuan 3 persentase rata-rata minat menjadi 84,03\% dalam kategori baik. Pada pertemuan 3 siswa memiliki perasaan senang, keterlibatan, ketertarikan yang baik serta perhatian yang sangat baik. Siswa telah mengerti bagaimana asyiknya membuat Mind Mapping sehingga ketertarikan terhadap pembelajaran meningkat. Hal ini sesuai dengan penelitian lain yang menyatakan bahwa dengan menerapkan model Direct Instruction menggunakan teknik Mind Mapping membuat siswa senang dan bersemangat belajar [7]. Siswa tertarik belajar karena siswa diperkenankan membuat Mind Mapping sesuai kreativitas mereka [8].

\subsection{Kemampuan siswa membuat Mind Mapping}

Siswa diberikan tugas untuk membuat mind sesuai materi yang telah diajarkan guru. Berdasarkan tugas evaluasi yang dinilai peneliti berdasarkan indikator, di dapatkan hasil kemampuan membuat Mind Mapping yang dapat dilihat pada grafik gambar 2.

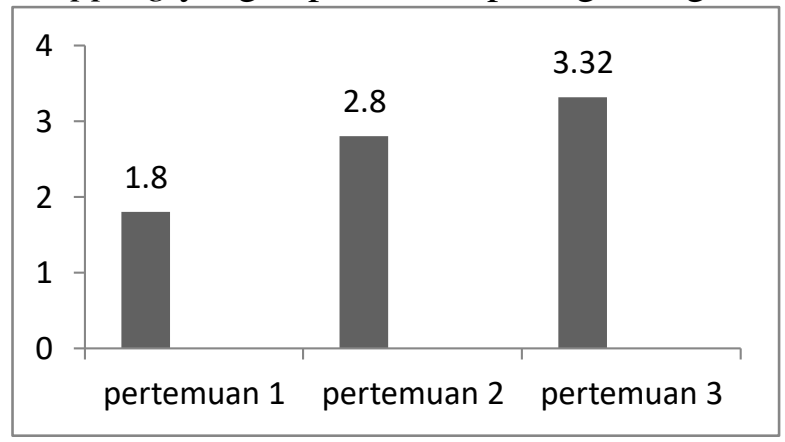

Gambar 2. Grafik skor rata-rata kemampuan siswa membuat Mind Mapping.

Berdasarkan gambar 2, pada pertemuan 1 skor rata-rata kemampuan membuat Mind Mapping siswa adalah 1,8 dalam kategori cukup. Hal ini bisa disebabkan karena siswa belum mengenal dan memahami metode Mind Mapping dengan baik. Siswa sulit memahami metode Mind Mapping dikarenakan siswa kurang fokus pada pembelajaran yang dilakukan pada saat classmeeting. Pada pertemuan 2 skor rata-rata kemampuan membuat Mind Mapping meningkat menjadi 2,8 dalam kategori baik. Hal ini dikarenakan siswa sudah bisa mengenal dan memahami Mind Mapping. Pada pertemuan 3 skor rata-rata Mind Mapping adalah 3,32 dalam kategori sangat baik. Hal tersebut dikarenakan siswa merasa senang saat membuat Mind Mapping dengan gambar dan warna menarik sehingga catatan menjadi lebih mudah dimengerti. Hal ini sejalan dengan penelitian lain yang mengungkapkan bahwa kemampuan membuat Mind Mapping siswa meningkat setelah mengerti bagaimana membuat Mind Mapping seiring dengan bertambahnya pengalaman dan rasa percaya diri dalam membuat Mind Mapping [9].

\subsection{Hasil Belajar}

Pada penelitian ini peneliti menggunakan model Direct Instruction berbasis Mind Mapping, siswa diberikan test berisi 5 butir soal berdasarkan materi kalor. Pada pertemuan 1 nilai rata-rata siswa berada dalam kategori di bawah KKM. Pada pertemuan 2 nilai rata-rata hasil belajar siswa mengalami peningkatan jika dibandingkan nilai rata-rata hasil belajar siswa pada pertemuan 1 . Namun nilai rata-rata hasil belajar pertemuan 2 masih dalam kategori di bawah KKM. Pada pertemuan 3 nilai rata-rata hasil belajar siswa mengalami peningkatan dalam kategori di atas KKM. Peningkatan hasil belajar dapat dilihat pada gambar 3.

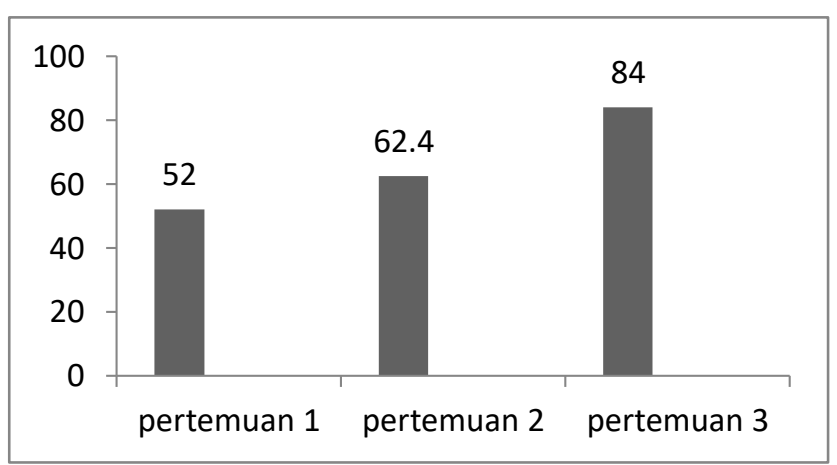

Gambar 3. Grafik nilai rata-rata hasil belajar siswa 
Terlihat pada grafik pada gambar 1 , pada pertemuan 1 nilai rata-rata siswa adalah 52 . Nilai rata-rata pada pertemuan 1 masih berada dibawah KKM dengan kategori sangat kurang. Pada pertemuan 2 nilai rata-rata siswa mulai menunjukkan peningkatan yaitu menjadi 62,4. Nilai ratarata pertemuan 2 masih berada dibawah KKM dengan kategori sangat kurang. Hal ini bisa dikarenakan siswa kurnag fokus dalam belajar dan belum memahami metode mencatat dengan Mind Mapping. Pertemuan 3 siswa memiliki minat yang baik sehingga nilai rata-rata hasil belajar siswa mengalami peningkatan menjadi 84 yang berarti nilai rata-rata siswa di atas KKM dan dalam kategori sangat baik. Dikarenakan siswa sudah memiki perasaan senang yang baik dan memiliki perhatian yang sangat baik yang berarti siswa memiliki minat yang baik. Pada pertemuan 3 nilai rata-rata hasil belajar siswa mengalami peningkatan nilai yang tinggi. Hasil belajar yang mengalami peningkatan nilai yang tinggi bisa disebabkan oleh faktor internal dan eksternal. Salah satu faktor internal adalah minat belajar siswa. Pada pertemuan 3 siswa telah memiliki minat belajar yang baik dan didukung dengan faktor eksternal seperti motivasi dari guru dan metode belajar yang menarik, yakni membuat Mind Mapping. Hal ini sesuai dengan penelitian yang lain yang menyatakan bahwa perasaan senang dan ketertarikan dalam belajar menggunakan Mind Mapping dapat meningkatkan hasil belajar siswa karena dengan mind maping siswa lebih mudah mengingat dan memahami materi pelajaran $[7,9,10]$.

\section{Kesimpulan}

\subsection{Kesimpulan}

Berdasarkan hasil penelitian dan pembahasan, dapat diambil kesimpulan bahwa 1) minat belajar siswa kelas VII D SMP Negeri 3 Kepahiang dengan menggunakan model Direct Instruction berbasis Mind Mapping pada pertemuan I persentase minat belajar siswa dalam kategori kurang, pada pertemuan II persentase minat belajar siswa dalam kategori kurang, pada pertemuan III persentase minat belajar siswa dalam kategori baik, 2) Kemampuan membuat Mind Mapping siswa kelas VII D SMP Negeri 3 Kepahiang dengan menggunakan model Direct Instruction berbasis Mind Mapping pada pertemuan I diperoleh skor rata-rata siswa dalam kategori cukup, pada pertemuan II diperoleh skor rata-rata kelas dalam kategori sangat baik, dan pada pertemuan III diperoleh skor rata-rata kelas siswa sebesar 83 dalam kategori baik serta 3) hasil belajar siswa kelas VII D SMP Negeri 3 Kepahiang dengan menggunakan model Direct Instruction berbasis Mind Mapping pada pertemuan I diperoleh hasil belajar siswa dalam kategori sangat kurang, pada pertemuan II diperoleh hasil belajar siswa dalam kategori sangat kurang, dan pada pertemuan III diperoleh hasil belajar siswa dalam kategori sangat baik.

\subsection{Saran}

Saran bagi peneliti selanjutnya adalah hasil penelitian ini dapat dijadikan bahan referensi untuk dapat meningkatkan variabel yang mempengaruhi hasil belajar, karena pada dasarnya terdapat faktor internal maupun faktor eksternal lain selain faktor di atas yang berpengaruh terhadap hasil belajar siswa.

\section{DAFTAR PUSTAKA}

[1] Trianto, 2009, Mendesain Model Pembelajaran Inovatif Progresif Konsep, Landasan dan Implementasinya pada Kurikulum Tingkat Satuan Pendidikan (KTSP), Kencana Prenada Group, Jakarta.

[2] Swadarma, D., 2013, Penerapan Mind Mapping dalam Kurikulum Pembelajaran, Kompas Gramedia, Jakarta.

[3] Deporter, B. dan Hernacki, M., 2016, Quantum Learning, PT Mizan Pustaka, Bandung.

[4] Buzan, T., 2005, Buku Pintar Mind Map, Gramedia, Jakarta.

[5] Ahmadi, A., 2009, Psikologi Sosial, Rineka Cipta, Jakarta.

[6] Djaali, 2008, Psikologi Pendidikan, Bumi Aksara, Jakarta. 
[7] Nafsi, A. Z., Budiningarti, H., dan Martini, 2013, Penerapan Model Direct Instruction dengan Teknik Mind Mapping pada Tema Perkaratan Logam Besi untuk Meningkatkan Hasil Belajar Siswa, Jurnal Pendidikan Sains e-Pensa, No. 2, Vol. 1, hal. 110-117.

[8] Venisari, R., Gunawan, dan Sutrio, 2015, Penerapan Metode Mind Mapping Pada Model Direct Instruction untuk Meningkatkan Kemampuan Pemecahan Masalah Fisika Siswa SMPN 16 Mataram, Jurnal Pendidikan Fisika dan Teknologi, No. 3, Vol. 1, hal 193-198.

[9] Winarni, Rusijono, dan Subrto, W. T., 2015, Penerapan Model Pembelajaran Langsung dengan Mind Mapping untuk Meningkatkan Hasil Belajar IPS materi pokok perkembangan teknologi di Kelas Iv SD Karen Bantul, Jurnal Review Pendidikan Dasar, No. 1, Vol. 1, hal. 35-42.

[10] Saputro, L.E. dan Airlanda, G. S., 2019, Upaya Peningkatan Proses dan Hasil Belajar IPA Tema 4 Subtema 1 dengan Model Pembelajaran Mind Mapping Siswa SD Kelas 4, Jurnal Basicedu, No. 1, Vol. 3, hal. 11-15 